DOI: http://doi.org/10.21698/simi.2017.0042

\title{
USING TECHNOLOGY AS KEY ELEMENT IN CREATING RATIONALITY IN NATURAL RESOURCES USAGE
}

\author{
Dumitru-Alexandru Bodislav, Florina Bran
}

The Bucharest University of Economic Studies, 2-10 Caderea Bastiliei, Bucharest, Romania, alex.bodislav@ase.ro

\begin{abstract}
This research article starts from the premise that we need to emphasize the idea of scarcity to protect our rational way of consuming our Earth's natural resources. From Stone Age agriculture till today's Internet of Things which can used in agriculture, we came a long way. This paper presents the competitive advantage offered by technology and by human behaviour moulded by speedy communications towards creating a special path that could be seen as optimized agriculture.
\end{abstract}

Keywords: agriculture, economics, natural resources, rationality, technology

\section{Introduction}

Over the years, the growth was a strong force to reduce poverty, creating jobs and improving general living conditions. Before the 18th century the world economy has experienced low growth. Growth theory has its roots in the eighteenth century is developing amid the Industrial Revolution, revolution led to higher yields of production factors in a surprising manner. So, at that time, economic growth has been associated with a significant increase of production at the company level (Bodislav \& Bran 2017). According to economic historian, James Bradford DeLong, global growth was $0.3 \%$ per year between 1300 and 1700 , and only $0.6 \%$ per year between 1700 and 1800 . But in the 19th century, growth reached $2.7 \%$ per year as a result of industrialization in UK, US, France, Germany and Japan.

Decades of research economists have emphasized the central role that innovation has in terms of generating long-term economic growth. Therefore, development of science and technological changes occurring as a result of continuing innovation is a key - the key economies today.

Innovation has played an important role in terms of employment expansion. Progress in health technology have led to a dramatic increase in life expectancy. If in the 1800s, the average life expectancy at birth was under 40 years in all developed countries by 2011, this had risen to more than 75 years, the highest average was recorded in Japan, respectively 83 years.

Currently, there are many areas of innovation to stimulate growth potential in the future, and these include: nano-biotech, intelligent robots, 3D printers, and genetics. However, in order to stimulate economic growth, it is necessary for new technologies to widely publicize the economy. It is also necessary that the current economy possess sufficient absorption capacity to hold human capital able to understand and apply new technologies, have the know-how and have the institutions to coordinate and mobilize resources to implement new technology (Bodislav \& Bran 2017). 


\section{INTERNATIONAL SYMPOSIUM "THE ENVIRONMENT AND THE INDUSTRY", SIMI 2017, PROCEEDINGS BOOK}

\section{Results and Discussion \\ Efficiency as part of agricultural innovation}

Trade between traders, agricultural producers and customers made in due time, taking into account the perishability of goods, requires a high efficiency in the distribution structure that may involve an extra cost mainly borne by the customer.

These exchanges are limited and geographical location of agricultural land use, road infrastructure and population distribution, so to have highlighted the links between traders, farmers and customers have drawn connections and competitive advantage created by technological advances (Bran \& Bodislav 2012).

Technological advances created through the used transport system, the innovative agricultural systems used and the real-time distribution to the customer, to which we can add the optimal development of the farms in order not to enter into exogenous or endogenous production cycles.

The agricultural industry based on timely distribution to the trader and the customer by the farmer is based on economically efficient processes that include three evolutionary factors: creating work standards, widespread deployment and optimizing dead times. As an example, we can take the evolution of a tomato, which, although strictly natural, can be controlled and manipulated anthropically (Bodislav 2011). A tomato-based factory (tomato juice, ketchup, whole preserved tomatoes, etc.) requires an optimized technological flow to avoid creating high dead-time costs.

The working framework of the agricultural crop-process process must also be optimized through the timely distribution system. That the whole picture be complete also needs to be borne in mind that there are also the environmental and health standards of the crop (if the obtained vegetables are bio, eco or GMOs), which are now also a factor evaluated by the consumer, not only by competent agencies (Low \& Vogel 2011).

If large merchants are taken as a valuation pool, with the top three at global level being in 2011: Wal-Mart, Tesco and Carrefour, they can see that they attach greater importance to offering the consumer as green as possible, through spaces addressed to the customer Depending on its preferences and area of origin.

In connection with the area of origin referring to the US market in particular (Kummer 2010) where Wal-Mart is trying to bridge the gap between the farmer and the final customer, reaching even to impose conglomerates local to introduce a policy of financial support to farmer's subcontractors (Whole Foods 2011).

These new product features result in new supply chain needs, decreasing production distance but increasing workflow. To increase the efficiency of distribution to the trader (or final customer), the work and development strategy has been attributed to the carrier as it can optimize dead times by calculating production, harvesting, processing and shipping times for the trader, and to provide it with a Life of the product so that it does not cause loss due to expiration of the shelf life.

We can introduce here the idea of a trader as a symbol of operational efficiency by the fact that the big retailers come from developed countries that have access to global distribution and development, creating a scalable model for optimum output (in terms of volume and time).

To gain access to shelf life, major retailers incorporate domestic producers, who have independence in the production decision, but not in delivery and volume. In order to lower the producer's costs, subcontracting the agricultural conglomerate and the 


\section{INTERNATIONAL SYMPOSIUM "THE ENVIRONMENT AND THE INDUSTRY", SIMI 2017, PROCEEDINGS BOOK}

retailer's purchase, the producer is retired on a single agricultural product or just on an agricultural class.

This chosen path has been partially imposed because studies suggest that there is a loss of quality through industrial production methods and in terms of nutritional value but also by the minimum standards reached (USDA).

Between 1950 - 2000, it had a loss of crop nutrition $6 \%$ protein and $38 \%$ riboflavin (Davis et al. 2004; Ata et al. 2012), but an increase in the level of pesticides (EWG 2011) and chemical fertilizers circuit are naturally found in ground water in the agricultural area (Berman et al. 2005).

\section{Fresh versus rotten - the technological output for perishable natural resources}

Why is there such results that affect product quality, ambient environment and consumer health? Because they have a high shelf life, productivity is above normal, and these products look very "healthy" and fresh all the time. These are the characteristics of mass production, low quality nutrition and spending a lot of time in the distribution flow. The alternative of the moment is given by the local production, which besides the indirect aid granted to the local economy and the national macroeconomic indicators also has some qualitative specific features:

1. Agricultural crops do not spend a lot of time in processing (time $=$ money, less time spent, lower cost per piece, greater profit);

2. "Healthy" prospect (the product is freshly preserved naturally without chemical improvement);

3. The agricultural production method is environmentally friendly.

We can see such production as a component of horizontal development in the agribusiness, which is part of the vertical distribution to the final consumer that the product supports multiple payment complementary industries (Bran \& Bodislav 2012). Local production is thus the first step towards agricultural health but at the expense of global production, super-industrialized or super-chemically processed.

It can be considered as one of the only viable long-term outsourcing models. In the case of a company, the outsourcing process has a long-term tendency to destroy organizational culture and block the company, creating a malicious addiction to the chances of creating a competitor in the subcontracted company.

The balance obtained through the process of outsourcing production by an agricultural conglomerate is unique because it is a long - term win - win situation. To outsource globally a global conglomerate process, it must be synchronized with the trader's distribution system by translating the distribution network's working structure, basically either by optimizing the farmer's / processor relationship with the merchant's chain of stores, or by creating continuous-flow warehouses, From which to supply the merchant's stores (there are costs of extra storage and new distribution costs on the warehouse-store relationship), and the high level of competition does not allow the use of price discrepancies. Wal-Mart has developed the Heritage Agriculture Program to highlight both distribution structures, but highlighting local character and keeping pace with competition prices.

\section{Conclusions}

In the production and development cycle of the subcontracted producer (externality) there is also the need to implement the agricultural cycle, which includes the efficiency of the crop through exogenous factors (weather and pests). 


\section{INTERNATIONAL SYMPOSIUM "THE ENVIRONMENT AND THE INDUSTRY", SIMI 2017, PROCEEDINGS BOOK}

In agricultural production models, there is the Three Sisters model, which is based on alternating cultivation: corn, beans and pumpkins at the same time on the same arable land (corn provides the climbing structure for beans, the beans provide the necessary nitrogen for the corn, and the pumpkins do not allow access pests and soil covering (Fullerton 2001). This is a practical balance of the hedge agricultural base model.

For the outsourcing process, we also have major implications for the development of product and brand standards according to the conglomerate or retailer for which it is produced, here we can mainly include processed products, but in the case of unprocessed products (e.g. tomatoes delivered to traders) Have specifications according to USDA or European Commission, but not by taste or nutritional quality. If we call into question olfactory senses, we can see major differences between the taste of a "garden" tomato and a tomato produced for the market, although both look the same. Local producers, subcontracted by agricultural conglomerates or traders, intervene here as they can bring the following features as an advantage over competition:

Natural taste;

High nutritional values;

Methods of ecological cultivation.

It should be noted that certain production processes are viable only in certain areas and therefore the implementation and feasibility process should be followed up by studying the soil, climate, anthropic environment and available infrastructure characteristics, also taking into account the relationship developed during the research: The distance between a city and city center and an agricultural producer is directly proportional to the arable land available for cultivating the necessary agricultural products. In the long term, the influence of innovation on the IT \& C sector may be the one that will create a rupture in the traditional production, distribution and marketing of organic, organic, organic and natural products, which may lead to removal from the chain of retailers', but the results are to the benefit of the end user, the bio consumer. This will certainly be part of the disruption of the future when it comes to rational consumption of natural resources and maximizing their output by using the IT \& C component and maybe its newest branch, the Internet of Things, this way we will reach a breakthrough like BASF did at the beginning of the $20^{\text {th }}$ century when they introduced the chemical fertilizer and increasing productivity per hectare 100 times in only one year, evolution never seen since then.

\section{References}

Ata, B, Lee, D, Tongarlak, MH 2012, 'Got local food', Harvard Business Review, no. 1 .

Berman, J, Arrigo, KR, Matson, PA 2005, 'Agricultural runoff fuels large phytoplankton blooms in vulnerable areas of the ocean', Nature, no. 435, pp. 211-214.

Bodislav, DA 2015, 'The impact of privatisation on regulated energy markets: a Great Britain's case study in industrial ecology', Progress in Industrial Ecology, vol. 9, no. 1, pp. 13-18.

Bodislav, DA 2011, 'The eco-innovation approach for the energy of the future', Quality-Access to Success, vol. 12, no. 121, pp. 358-363. 
Bodislav, DA \& Bran, F 2017, 'Reducing the technology gap. Romania versus EU. EU and Israel versus USA', Quality - Access to Success, vol. 18, no. S2, pp. 69-72.

Bran, F \& Bodislav, DA 2012, 'Locally or Globally: Agribusiness from the globalization's perspective', chapter in Agri-Environment: Perspectives on Sustainable Development, Bioflux Publishing, Gembloux.

Davis, DR, Epp, MD, Riordan, HD 2004, 'Changes in USDA food composition data for 43 garden crops, 1950-1999', Journal of the American College Nutrition, no. 23 , pp. 669-682.

Environmental Working Group, EWG's Shopper's Guide to Pesticides in Produce, 2011, Available from: http://www.ewg.org/foodnews/ [23.07.2017].

Fullerton, D 2001 'A framework to compare environmental policies', Southern Economics Journal, vol. 68, no. 2, pp. 224-248.

Kummer, C 2010, 'The great grocery smack down', The Atlantic, no. 3.

Low, SA \& Vogel, S 2011, 'Direct and intermediated marketing of local foods in the United States', USDA Economic Research Report, no. 128.

Whole Foods, Locally grown: the Whole Foods market premise, 2011, Available from:

http://www.wholefoodsmarket.com/products/locally-grown/ [23.07.2017]. 